The $3{ }^{\text {rd }}$ Conf. of SSFOP "Recent Techniques in Ornamental Plants Scope", Cairo, Egypt, 26/2/2017

Scientific J. Flowers \& Ornamental Plants

www.ssfop.com/journal

ISSN: 2356-7864

\title{
THE USE OF HUMIC ACID AND EM IN REPLACEMENT OF NPK CHEMICAL FERTILIZATION FOR THE PRODUCTION OF GARDENIA JASMINOIDES POT PLANTS
}

\author{
F.S. Badran ${ }^{*}$, M.A. Abdou* , A.A. El-Sayed ${ }^{*}$, Boshra A. El-Sayed ${ }^{* *}$ and A.A. Gohar ${ }^{* *}$ \\ * Fac. Agric., Minia Univ., Egypt. \\ ** Ornamental Plants and Landscape Gardening Res. Dept., Hort. Res. Inst., ARC, Giza, Egypt.
}

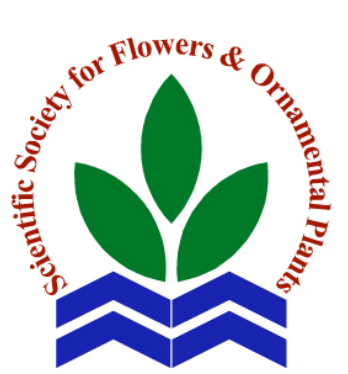

Scientific J. Flowers \& Ornamental Plants, 4(1):121-130 (2017).

Received: 5/1/2017

Accepted: $24 / 1 / 2017$

ABSTRACT: A pot experiment was conducted under greenhouse conditions at the Hort. Res. Inst., ARC, Giza, Egypt during the two successive seasons 2014 and 2015 to explore the possibility of using humic acid (H) and/or effective microorganisms (EM) instead of NPK chemical fertilization for producing Gardenia jasminoides pot plants.

Obtained results indicated that NPK fertilization treatment, as well as, humic acid and/or EM treatments caused great and considerable enhancement in different vegetative growth characters, flowering parameters and chemical constituents in comparison with control treatment. Hence, both NPK and other stimulant treatments ( $\mathrm{H}$ and/or EM) gave nearly similar values for growth and flowering traits.

Therefore, it is advised, from the economical and environmental point of view, to use such stimulants ( $\mathrm{H}$ and /or EM) in replacement of NPK chemical fertilizers for producing good quality pot plants of Gardenia jasminoides.

Key words:Gardenia jasminoides, humic acid, effective microorganisms (EM), NPK, vegetative growth, flowering, chemical constituents.

\section{INTRODUCTION}

Gardenia jasminoides, Ellis belongs to family Robiaceae is native to China. It is an evergreen shrub with glossy, bright green leaves and double white highly fragrant flowers, 5-10 cm across commonly borne singly in the leaf axes (Williamson, 1975). Gardenia grows successfully outdoors and in large containers and it does well indoors as pot plant. It requires a rich, moist acidic $(\mathrm{pH}$ 5-5.5) and well-drained soil high in organic matter. In addition, it has poor to low salt tolerance and moderate wind resistance (Kobayashi and Kaufman, 2006). In regard to landscape uses, Gardenia plants with their glossy, dark green foliage, make a great foundation in the landscape. It is effectively used as either focus or background in informal plantings and is a popular cut flower for the florist. Concerning growing Gardenia indoors, it should receive plenty of bright light, preferably direct sunshine for at least half a day in a sunny south or west window. It prefers temperature close to 16 ${ }^{\circ} \mathrm{C}$ at night and $21-24{ }^{\circ} \mathrm{C}$ during the day. Maintain uniform moisture and good drainage in the growth medium (Kobayashi and Kaufman, 2006).

The role of NPK in augmenting vegetative growth, flowering traits and chemical constituents but delaying flowering date was reported by many authors such as Badran et al. (1989 a) and Abdou (2002) on borage; Badran et al. (1989 b) on calla; Khalil and Helal (1998) on geranium; Badran et al. (2001), Sayed (2004) and 


\section{F.S. Badran et al.}

Hassan (2016) on Gladiolus. The positive effect of NPK fertilization was also demonstrated by Ashour (2006) on Ficus elastica; Barsoom (2008) on Voila adorata; Kandeel et al. (2008) on Jasminum grandiflorum; El- Sayed (2012) on Seashore paspalum and Badran et al. (2016) on Moringa oleifera. Meanwhile, the role of humic acid in promoting growth, flowering and/or chemical constituents was obtained on Ficus benjamina (Siraj et al., 2001); four ornamental plants (Evans and Li, 2003); pot marigold (Azzaz et al., 2007); turfgrass plants (El-Sayed et al., 2008 and El- Sayed. 2012) Dracaena and Ruscus (Abd-Elfattah et al., 2009); Gladiolus (Ahmed et al., 2013) and Gazania (Yukun et al., 2014). The stimulating influence of EM was revealed by Thach et al. (1999) on orchid plants, AbdElraoof (2009) on borage; Romualad and Tomasz (2010) on Gerbera; Ashour (2010) on jojoba; El-Sayed (2012) on Seashore paspalum; Ali (2013) on pot marigold; AbdEllatif (2014) on Lavander; Wang et al. (2015) on three container plants; SchroeterZekrzewska et al. (2016) on geranium and Hassan (2016) on Gladiolus.

The aim of the present investigation was to explore the possibility of using some natural stimulants, like humic acid and effective microorganisms (EM), in replacement of NPK mineral fertilization in producing quality pot plants of Gardenia jasminoides.

\section{MATERIALS AND METHODS}

A pot experiment was conducted in the greenhouse of the Dept. of Floriculture, Hort. Res. Institute, Agric. Res. Center, Giza, Egypt during 2014 and 2015 successive seasons to explore the influence of five fertilization treatments on growth, flowering and chemical constituents of Gardenia jasminoides, Ellis plants.

Rooted cuttings of Gardenia with average height of $5 \mathrm{~cm}$, obtained from Safwat Habib nursery, Kerdasa, Giza, were transplanted on the first week of March for both seasons to $20 \mathrm{~cm}$ plastic pots filled with peatmoss. After transplanting, Mooncut fungicide was added as soil drench, and chelated ferrous at the rate of $150 \mathrm{ppm}$ was foliar sprayed every month along the whole growing season. The experimental layout of this trial was complete randomized block design with three replicates and five plants/replicate. The five fertilization treatments were control, NPK (Kristalon 19:19:19), humic acid (H), effective microorganisms EM) and $\mathrm{H}+$ EM. NPK (Kristalon) was added at the rate of $2.0 \mathrm{~g} / \mathrm{pot}$ every 2 weeks, humic acid $(\mathrm{H})$ and EM were supplied at the rate of $5 \mathrm{~cm}^{3} / 1$ and $1 \mathrm{~cm}^{3} / 1$, respectively, every 2 weeks. The three fertilizers were applied as soil drench after one week from transplanting for the two seasons. Physical and chemical properties of the used peatmoss, for both seasons are given in Table (a).

Table a. Physical and chemical properties of the used peatmoss in the two seasons.

\begin{tabular}{lclc}
\hline \multicolumn{1}{c}{ Properties } & Values & Properties & Values \\
\hline $\begin{array}{l}\text { Org. Matter (\%) } \\
\text { Ash (\%) }\end{array}$ & $80-95$ & P (\%) & 0.23 \\
$\begin{array}{l}\text { Density (Vol D.W. } \\
\text { mg/l) }\end{array}$ & $80-90$ & K (\%) & 1.77 \\
pH & 3.4 & Mn (ppm) & 421.0 \\
$\begin{array}{l}\text { Water retention } \\
\text { cap. (\%) }\end{array}$ & $60-75$ & Zn (ppm) & 41.0 \\
$\begin{array}{l}\text { Salinity (mg/l) } \\
\text { N (\%) }\end{array}$ & 0.3 & Cu (ppm) & 8.8 \\
\hline
\end{tabular}

On the first week of Oct. for each season the following vegetative growth characters and flowering parameters were recorded: plant height $(\mathrm{cm})$, stem diameter $(\mathrm{mm})$, branch number/plant, leaf area $\left(\mathrm{cm}^{2}\right)$, leaf number/plant, leaves fresh weight/plant, flowering date (day), flowers number/plant and flowers fresh weight/plant (g.).

\section{Chemical constituent determinations:}

The three photosynthetic pigments (chlorophyll a, chlorophyll b and carotenoids contents) were colourmetrically determined according to Saric et al. (1976). While, nitrogen, phosphorus and potassium \% were determined by the modified microkjeldahl 
method (Plummer, 1971) for nitrogen; colormetrically (Jackson, 1958) for phosphorus and flame- photometer (Piper, 1950) for potassium. Meanwhile, total carbohydrates were estimated following the method of Dubois et al. (1956), while each of total indoles and total phenols were determined following the method described by Daniel and George (1972).

Obtained data for vegetative, flowering and chemical constituent parameters were statistically analyzed according to the L.S.D. method described by Little and Hills (1978).

\section{RESULTS AND DISCUSSION}

\section{Vegetative growth characters:}

Obtained data in Tables (1 and 2) showed that all six vegetative growth characters of Gardenia jasminoides plants, namely, plant height, stem diameter, branch number/plant, leaf area, leaves number/plant and leaves fresh weight/plant were significantly increased, in the two seasons, in comparison with those of control plants.
However, the highest values for stem diameter, branch number, leaves number and leaves fresh, weight/plant were given due to NPK and humic + EM treatments, while, the best results for plant height and leaf area were obtained from humic acid and/or EM treatments. These results were almost identical in both seasons, (Tables 1 and 2). Therefore, it could be said that the humic acid + EM combined treatment was the most overall effective one in producing the tallest plants, thickest stems, most branch and leaves number and leaf area and heaviest leaves fresh weight. The increase in plant height, stem diameter, branch number, leaf area, number of leaves and leaves fresh weight due to such treatment $(\mathrm{H}+\mathrm{EM})$ reached 48.5, 22.5, 48.8, 31.7, 34.1 and $14.1 \%$ in comparison with control treatment in the first season. Similar trend was observed in the second season as clearly shown in Tables (1 and 2).

Table 1. Effect of fertilization treatments on plant height, stem diameter and branch number of Gardinia jasminoides during 2014 and 2015 seasons.

\begin{tabular}{lcccccc}
\hline \multirow{2}{*}{ Treatments } & \multicolumn{2}{c}{ Plant height $\mathbf{( c m )}$} & \multicolumn{2}{c}{ Stem diameter (mm) } & \multicolumn{2}{c}{ Branch number/plant } \\
& $\mathbf{2 0 1 4}$ & $\mathbf{2 0 1 5}$ & $\mathbf{2 0 1 4}$ & $\mathbf{2 0 1 5}$ & $\mathbf{2 0 1 4}$ & $\mathbf{2 0 1 5}$ \\
\hline Control & 32.8 & 30.6 & 4.62 & 4.25 & 3.28 & 3.51 \\
NPK & 36.6 & 34.0 & 5.82 & 5.62 & 4.94 & 4.72 \\
Humic acid (H) & 48.1 & 44.2 & 5.11 & 4.92 & 4.36 & 4.25 \\
EM & 49.3 & 43.8 & 5.08 & 4.88 & 4.44 & 4.16 \\
H + EM & 48.7 & 43.0 & 5.66 & 5.58 & 4.88 & 4.54 \\
L.S.D. 5\% & 2.4 & 2.7 & 0.36 & 0.40 & 0.42 & 0.35 \\
\hline
\end{tabular}

EM= Effective microorganisms.

Table 2. Effect of fertilization treatments on leaf area, leaves number and leaves fresh weight of Gardinia jasminoides during 2014 and 2015 seasons.

\begin{tabular}{lcccccc}
\hline \multirow{2}{*}{ Treatments } & \multicolumn{2}{c}{ Leaf area $\mathbf{( c m}^{\mathbf{2}}$ ) } & \multicolumn{2}{c}{ Leaves number/plant } & \multicolumn{2}{c}{ Leaves F.W. (g) } \\
& $\mathbf{2 0 1 4}$ & $\mathbf{2 0 1 5}$ & $\mathbf{2 0 1 4}$ & $\mathbf{2 0 1 5}$ & $\mathbf{2 0 1 4}$ & $\mathbf{2 0 1 5}$ \\
\hline Control & 18.9 & 16.0 & 53.3 & 51.8 & 19.9 & 17.8 \\
NPK & 20.6 & 17.8 & 70.2 & 66.6 & 24.7 & 22.5 \\
Humic acid (H) & 24.8 & 21.6 & 64.5 & 61.9 & 21.5 & 19.3 \\
EM & 24.6 & 22.3 & 64.9 & 62.3 & 21.4 & 20.5 \\
H + EM & 24.9 & 22.1 & 71.5 & 65.8 & 23.7 & 22.7 \\
L.S.D. 5\% & 1.4 & 1.6 & 4.4 & 5.6 & 1.2 & 1.1 \\
\hline
\end{tabular}

EM= Effective microorganisms. 


\section{F.S. Badran et al.}

The role of NPK in augmenting various vegetative growth characters was revealed by Badran et al. (1989 a) on borage; Badran et al. (1989 b) on calla, Badran et al. (2001) on Gladiolus; Ashour (2006) on Ficus elastica; Barsoom (2008) on Viola odorata Kandeel et al. (2008) on Jasminum grandiflorum; ElSayed (2012) on Seashore Paspalum and Badran et al. (2016) on Moringa oleifera. While, that of humic acid was reported by Siraj et al. (2001) on Ficus benjamina; Azzaz et al. (2007) on pot marigold; ElSayed (2008) and El- Sayed et al. (2012) on turfgrasses; Abd-Elfattah et al. (2009) on Dracaena and Ruscus and Yukun et al. (2014) on Gazania. Meanwhile, other authors emphasized the importance of EM in enhancing vegetative growth of orchid (Thach et al., 1999); borage (Abd-Elraoof, 2009); Jojoba (Ashour, 2010); Seashore Paspalum (El-Sayed. 2012); pot marigold (Ali, 2013); Lavander (Abd-Ellatif, 2014); three container plants (Wang et al., 2015) and Gladiolus (Hassan, 2016).

\section{Flowering parameters:}

Flowering date was differently and significantly influenced by the examined fertilization treatments in the present investigation as NPK treatment caused significant delay (9.8 and 12.6 days in the first and second seasons, respectively) in regard to unfertilized treatment, (Table 3). In contrast, humic acid, EM and humic + EM treatments produced significantly earlier flowers than those of unfertilized plants (about 8-10 days in the first season and 8-9 days in the second season) as illustrated in Table (3). Concerning number of flowers/plant and flowers fresh weight/plant, both flowering parameters were dramatically increased, in the two seasons, due to all four tested treatments comparing to control treatment. Both number and fresh weight of flowers, for each one of the four fertilized treatments were almost gave as much as double values of those recorded for control plants. However, NPK and humic + EM treatments were superior to humic or EM treatments as clearly indicated in Table (3).

In accordance with these findings concerning NPK were those found by Badran et al. (1989a) and Abdou (2001) on borage; Badran et al. (1989b) on calla; Badran et al. (2010) and Hassan (2016) on gladiolus; Barsoom (2008) on Viola odorata and Kandeel et al. (2008) on Jasminum grandioflorum. Meanwhile, the efficient role of humic acid on flowering aspects was mentioned by Evans and $\mathrm{Li}$ (2003) on four ornamental plants; Azzaz et al. (2007) on pot marigold; Ahmed et al. (2013) on gladiolus and Yukun et al. (2014) on Gazania. While that of EM was pointed out by Thach et al. (1999) on orchid; Abd-Elraoof (2009) on borage; Romuald and Tomasz (2010) on Gerbera; Ali (2013) on pot marigold; Schroeter-Zekrzewska et al. (2016) on geranium and Hassan (2016) on Gladiolus.

Table 3. Effect of fertilization treatments on flowering date, flower number and flower fresh weight of Gardinia jasminoides during 2014 and 2015 seasons.

\begin{tabular}{lcccccc}
\hline \multirow{2}{*}{ Treatments } & \multicolumn{2}{c}{ Flowering date (day) } & \multicolumn{2}{c}{ Flowers number/plant } & \multicolumn{2}{c}{ Flowers F.W. (g) } \\
& $\mathbf{2 0 1 4}$ & $\mathbf{2 0 1 5}$ & $\mathbf{2 0 1 4}$ & $\mathbf{2 0 1 5}$ & $\mathbf{2 0 1 4}$ & $\mathbf{2 0 1 5}$ \\
\hline Control & 50.5 & 44.4 & 3.61 & 4.02 & 10.3 & 11.7 \\
NPK & 60.3 & 57.0 & 8.35 & 8.40 & 39.3 & 43.3 \\
Humic acid (H) & 40.8 & 36.1 & 7.80 & 7.74 & 32.9 & 33.1 \\
EM & 42.2 & 35.8 & 7.62 & 7.66 & 31.9 & 32.9 \\
H + EM & 40.1 & 35.3 & 8.20 & 8.18 & 38.3 & 38.8 \\
L.S.D. 5\% & 4.7 & 5.1 & 0.49 & 0.72 & 2.8 & 2.6 \\
\hline
\end{tabular}

EM= Effective microorganisms. 


\section{Chemical constituents:}

\section{Photosynthetic pigments:}

Table (4) showed that the contents of the three photosynthetic pigments, chlorophyll a, chlorophyll b and carotenoids in the leaves of Gardenia plants were significantly promoted due to NPK, humic acid, EM and humic + EM treatments in comparison with those of control treatment in both first and second seasons. Among such four treatments, NPK gave significantly higher values, for the three pigments in both seasons, than those recorded by humic and/or EM treatments as illustrated in Table (4). In agreement with these results concerning NPK were those of Badran et al. (2001), Sayed (2004) and Hassan (2016) on Gladiolus; Ashour (2006) on Ficus elastica; Barsoom (2008) on Viola odorata; Kandeel et al. (2008) on Jasminum; El-Sayed (2012) on Seashore Paspalum and Badran et al. (2016) on Moringa. Regarding humic acid were the findings of El-Sayed et al. (2008) on tifway sod; Abd-Elfattah et al. (2009) on Dracaena and Ruscus and El-Sayed (2012) on Seashore Paspalum. In relation with EM were the results given by Thach et al. (1999), Abd-Elraoof (2009), Ali (2013), Abd-Ellatif (2014), Schroeter-Zekrzewska et al. (2016) and Hassan (2016) on orchid, borage, pot marigold, lavander, geranium and Gladiolus, respectively.

\section{Leaves percent of $\mathrm{N}, \mathrm{P}$ and $\mathrm{K}$ :}

Leaves percent of nitrogen, phosphorus and potassium were greatly and significantly stimulated as a result of supplying Gardenia plants with NPK, humic acid, EM and humic + EM treatments over the control plants as illustrated in Table (5). Among the prementioned four treatments, NPK gave significantly higher $\mathrm{N}, \mathrm{P}$ and $\mathrm{K} \%$ values than the other three treatments. Moreover, such three treatments did not show significant differences. All above mentioned results proved to be true in the two seasons as shown in Table (5). The role of NPK fertilization in promoting nitrogen, phosphorus and potassium \% was revealed by Badran et al. (1989b) on calla; Badran et al. (2001) and Sayed (2004) on Gladiolus; Barsoom (2008) on Viola odorata; Kandeel et al. (2008) on Jasminum grandiflorum and Badran et al. (2016) on Moringa oleifera. While that of humic acid was reported by Siraj et al. (2001). El- Sayed et al. (2008); Abd-Elfattah et al. (2009) and El-Sayed (2012) on Ficus benjamina, tifway sod, Dracaena and Seashore Paspalum, respectively. Similar response of $\mathrm{N}, \mathrm{P}$ and $\mathrm{K}$ $\%$ to EM application was mentioned by AbdElraoof (2009), Ashour (2010), Ali (2013), Abd-Ellatif (2014) and Hassan (2016) on borage, jojoba, pot marigold, lavander and Gladiolus, respectively.

\section{Total carbohydrates \%:}

Table (6) showed that total carbohydrates \% was significantly increased in both seasons, due to the four tested fertilization treatments (NPK, humic acid, $\mathrm{EM}$ and humic + EM) over control treatment. However, NPK treatment was much more effective than the other three treatments as it increased carbohydrates \% by nearly $100 \%$ over control treatment, while the other three treatments increased it by more than $50 \%$. These results proved to be true in the two experimental seasons, (Table 6). In close agreement with these results concerning NPK were the findings of Khalil and Helal (1998) on geranium, Sayed (2004) and Hassan (2016) on Gladiolus; Kandeel et al. (2008) on Jasminum grandifloruum and El-Sayed (2012) on Seashore paspalum. And regarding humic acid those found by El- Sayed et al. (2009) on tifway sod, Abd-Elfattah et al. (2009) on Dracaena and Ruscus and El-Sayed (2012) on Seashore Paspalum. Accordingly, EM was found to promote carbohydrates \% as reported by El-Sayed (2012) and Hassan (2016) on Seashore Paspalum and Gladiolus, respectively.

\section{Total indoles and total phenols:}

Both total indoles and total phenols were significantly promoted, in both seasons, due to supplying Gardenia plants with NPK, 
Table 4. Effect of fertilization treatments on chlorophyll a, chlorophyll b an carotenoids contents of of Gardinia jasminoides during 2014 and 2015 seasons.

\begin{tabular}{lcrcrcr}
\hline \multirow{2}{*}{ Treatments } & \multicolumn{2}{c}{ Ch. a $(\mathbf{m g} / \mathbf{g}$ F.W. } & \multicolumn{2}{c}{ Ch. b (mg/g F.W.) } & \multicolumn{2}{c}{ Carot. (mg/g F.W.) } \\
& $\mathbf{2 0 1 4}$ & $\mathbf{2 0 1 5}$ & $\mathbf{2 0 1 4}$ & $\mathbf{2 0 1 5}$ & $\mathbf{2 0 1 4}$ & $\mathbf{2 0 1 5}$ \\
\hline Control & 0.961 & 1.018 & 0.335 & 0.351 & 0.431 & 0.460 \\
NPK & 1.462 & 1.434 & 0.573 & 0.587 & 0.666 & 0.711 \\
Humic acid (H) & 1.280 & 1.350 & 0.420 & 0.549 & 0.552 & 0.610 \\
EM & 1.278 & 1.323 & 0.398 & 0.465 & 0.538 & 0.588 \\
H + EM & 1.340 & 1.329 & 0.440 & 0.532 & 0.575 & 0.632 \\
L.S.D. 5\% & 0.063 & 0.071 & 0.025 & 0.032 & 0.034 & 0.044 \\
\hline
\end{tabular}

EM= Effective microorganisms.

Table 5. Effect of fertilization treatments on the leaves \% of $\mathrm{N}, \mathrm{P}$ and $\mathrm{K}$ of Gardinia jasminoides during 2014 and 2015 seasons.

\begin{tabular}{lcccccc}
\hline \multirow{2}{*}{ Treatments } & \multicolumn{2}{c}{ Nitrogen (\%) } & \multicolumn{2}{c}{ Phosphorus (\%) } & \multicolumn{2}{c}{ Potassium (\%) } \\
& $\mathbf{2 0 1 4}$ & $\mathbf{2 0 1 5}$ & $\mathbf{2 0 1 4}$ & $\mathbf{2 0 1 5}$ & $\mathbf{2 0 1 4}$ & $\mathbf{2 0 1 5}$ \\
\hline Control & 2.23 & 1.96 & 0.270 & 0.252 & 1.38 & 1.31 \\
NPK & 3.04 & 2.66 & 0.463 & 0.409 & 1.76 & 1.63 \\
Humic acid (H) & 2.54 & 2.34 & 0.392 & 0.340 & 1.50 & 1.48 \\
EM & 2.48 & 2.30 & 0.400 & 0.325 & 1.52 & 1.52 \\
H + EM & 2.57 & 2.42 & 0.389 & 0.337 & 1.54 & 1.54 \\
L.S.D. 5\% & 0.12 & 0.14 & 0.015 & 0.020 & 0.07 & 0.08 \\
\hline
\end{tabular}

EM= Effective microorganisms.

Table 6. Effect of fertilization treatments on carbohydrates \%, total indoles and total phenols of Gardinia jasminoides during 2014 and 2015 seasons.

\begin{tabular}{lcccccc}
\hline \multirow{2}{*}{ Treatments } & \multicolumn{2}{c}{ Total carbohyd. (\%) } & \multicolumn{2}{c}{ Indoles (mg/100 g) } & \multicolumn{2}{c}{ Phenols (mg/100 g) } \\
& $\mathbf{2 0 1 4}$ & $\mathbf{2 0 1 5}$ & $\mathbf{2 0 1 4}$ & $\mathbf{2 0 1 5}$ & $\mathbf{2 0 1 4}$ & $\mathbf{2 0 1 5}$ \\
\hline Control & 20.5 & 15.2 & 0.442 & 0.302 & 0.111 & 0.094 \\
NPK & 40.8 & 38.0 & 0.588 & 0.479 & 0.322 & 0.296 \\
Humic acid (H) & 31.3 & 31.1 & 0.489 & 0.361 & 0.191 & 0.178 \\
EM & 31.7 & 32.2 & 0.492 & 0.358 & 0.179 & 0.172 \\
H + EM & 33.3 & 33.0 & 0.510 & 0.363 & 0.216 & 0.182 \\
L.S.D. 5\% & 1.9 & 1.5 & 0.018 & 0.022 & 0.009 & 0.014 \\
\hline
\end{tabular}

EM= Effective microorganisms.

humic acid, EM or humic + EM fertilization treatments in comparison with those of control plants. Among the four mentioned treatments, NPK was superior significantly over the other three treatment. Moreover, the combined humic $+\mathrm{EM}$ treatment gave higher values of indoles and phenols than each one alone. These results were almost identical for both first and second seasons as indicated in Table (6). In agreement with these results, regarding NPK were those of
Ashour (2006) on Ficus elastica and ElSayed (2012) on Seashore Paspalum, concerning humic acid those of El-Sayed (2012) on Seashore Paspalum and regarding EM were the findings of Ashour (2010), ElSayed (2012) and Abd-Ellatif (2014) on jojoba, Seashore Paspalum and lavander, respectively.

In order to explain the beneficial roles of NPK fertilization in enhancing growth, flowering and chemical constituents of 
Gardenia jasminoides, Ellis plants, it is convenient to refer, in brief, to the physiological roles of these elements, which considered to be the most common macronutrients in plant growth and development. Nitrogen is a constituent of all proteins, many enzymes and energy transfer materials such as chlorophyll, ADP and ATP. Growing plants must have nitrogen to form new cells and the rate of growth then becomes very nearly proportional to the rate at which nitrogen is supplied. Also, photosynthesis can produce soluble sugars from $\mathrm{CO}_{2}$ and $\mathrm{H}_{2} \mathrm{O}$, but the process cannot go on to the production of protein in absence of nitrogen. Thus, a severe shortage of nitrogen will halt the process of growth and reproduction (Bidwell, 1974). Phosphorus, which has been called the key to life, is essential for cell division and the development of meristimatic tissue and it is very important for carbohydrate transformation due to multitude of phosphorylation reaction and to energy rich phosphate bond (Lambers et al., 2000). Phosphorus compounds are essential for photosynthesis, the interconvention of carbohydrates and related glycolysis, amino acid metabolism, fat metabolism and biological oxidation. Lack of phosphorus, therefore, hampers metabolic processes such as the conversion of sugar into starch and cellulose (Devlin, 1972). Potassium is important for growth and elongation probably due to its function as an osmoticum and may react synergistically with IAA. Moreover, it promotes $\mathrm{CO}_{2}$ assimilation and translocation of carbohydrates from the leaves to the storage tissues (Mengel and Kirkby, 1987).

Humic acid, nowadays, is widely used for production of most crops, namely, vegetables, fruit trees, field crops, medicinal and aromatic plants, flowers and ornamental plants, as well as, indoor container plants. Humic acid provides soil microbs with energy, increases the availability of nutrients in the soil through its influence on soil microbial activity, release more nutrients necessary for healthy growth, decrease phosphate fixing capacity of the soil, improves nutrients retention in the soil, enhances water holding capacity, improves soil structure and acts as a source of N, P and $S$ for plants (Heng, 1989; Higa and Wididana, 1991 and Dorer and Peacock, 1997).

A commercial Japanese product, effective microorganisms (EM) is a biostimulant that contains more than 60 selected strains of effective microorganisms, viz, photosynthetic bacteria, lactic acid bacteria, yeast, actionomytes and various fungi that improves growth and health of plants (Primavesi, 1999). It have been introduced to the organic farming system in many countries, including Egypt. Treatment with EM led to larger stems. Darker green leaves and accelerated flowering. It is also effective in creating humus and improving soil properties, increasing plant disease resistance and may play a role in enhancing the enzymatic system in the plant tissues and consequently enhancing growth (Thach et al., 1999 and Janas, 2009). Furthermore, Primavesi (1999) suggested that EM promotes stroma lamella formation, chlorophyll appearance during normal leaf growth and stimulates total sugars, as well as, total indoles and total phenols.

\section{REFERENCES}

Abd-Elfattah, G.H.; El-Sayed, B.A. and Khenizy, S.A. (2009). Response of Dracaena and Ruscus plants to humic acid and biofertilizer supply. Ann. of Agric. Sci., Moshtohor, 47 (1):111-119.

Abd-Ellatif, M.H. (2014). Physiological Studies on Lavandula Officinalis Plants. Ph.D. Thesis, Fac. Agric., Minia Univ., Egypt.

Abd-Elraoof, R.M. (2009). Response of Borage Plants to Some Organic and Biofertilization Treatment. Ph.D. Thesis, Fac. Agric., Minia Univ., Egypt.

Abdou, M.A. (2002). Influence of NPK and micronutrients on growth, flowering and chemical constituents of Borago 


\section{F.S. Badran et al.}

officinalis, L. plants grown in sandy soil. Proc. Minia $1^{\text {st }}$ Conf. for Agric. \& Env. Sci., 22(2):1659-1672.

Ahmad, I.; Saquib, R.U.; Qasim, M. Salem, M.; Khan, A.S. and Yaseen, M. (2013). Humic acid and cultivar effects on growth, yield, vase life and corm characteristics of gladiolus. Chilean J. Agric. Res., 73:339-344.

Ali, F.A. (2013). Effect of Organic and Biofertilization Treatments on Pot Marigold, Calendula officinalis, L., Plants. M.Sc. Thesis, Fac. Agric., Minia Univ., Egypt.

Ashour, R.M. (2006). Physiological studies on the propagation of Ficus elastica var. Decora by Aerial Layering. M.Sc. Thesis, Fac. Agric., Minia Univ., Egypt.

Ashour, R.M. (2010). Response of Jojoba Plants to Some Organic and Biofertilization Treatments. Ph.D. Thesis, Fac. Agric., Minia Univ.

Azzaz, N.A.; Hassan, E.A. and El-Emary, F.A. (2007). Physiological, anatomical and biochemical studies on pot marigold (Calendula officinalis, L.) plants. African Crops Sci. Conf. Proc., Minia, Egypt, 8:1727-1738.

Badran, F.S.; Aly, M.K. and Al-Badawy, A.A. (1989a). Effect of soil type and NP fertilization treatments on growth, flowering and chemical composition of Borago officinalis, L. plants. Minia J. Agric. Res. \& Dev., 11(3):1073-1091.

Badran, F.S.; Al-Badawy, A.A. and Aly, M.K. (1989b). Effect of NPK fertilization treatments and spacing on the growth and flowering of Zantedeschia aethiopica, Spring. Minia J. Agric. Res. \& Dev., 11(3):525-535.

Badran, F.S.; Attia, F.A. and Abou-Elela, H.A. (2001). Response of gladiolus to different soil and foliar nitrogen, phosphorus and potassium fertilization treatments. Fifth Arabian Hort. Conf. Ismailia, Egypt, 157-168.
Badran, F.S. Taha, R.A.; El-Ghadban, E.A. and Ali, M.E. (2016). Effect of irrigation intervals and organic /mineral fertilization treatments on vegetative growth and chemical composition of Moringa oleifera plants. Minia J., Agric. Res. \& Dev., 36(2):233-247.

Barsoom, M. (2008). Physiological Studies on Violet (Viola odorata). M.Sc. Thesis, Fac. Agric., Kafr-Elsheikh Univ.

Bidwell, R.G. (1974). Plant Physiology, Macmillan Co. Inc. New York, U.S.A.

Daniel, H.D. and George, C.M. (1972). Peach seed dormancy in relation to indogenous inhibitors and applied growth substances. J. Amer. Soc. Hort. Sci., 97:651-654.

Devlin, R.M. (1972). Plant Physiology, Third Edit., Van Nostrand Co., New York, U.S.A.

Dorer, S.P. and Peacock, C.H. (1997). The effect of humate and organic fertilizer on establishment and nutrition of creeping bentgrass putting greens. Inter. Turfgrass Soc. Res. J., 8:437-443.

Dubois, M.; Smith, F.; Gilles, K.A.; Hammilton, J.K. and Robers, P.A. (1956). Colorimetric method to the determination of sugars and related substances. Anal. Chem., 28(3):350-356.

El-Sayed, B.A. (2012). Response of Seashore Paspalum to treatment with kristalon and biostimulant E.M. Minufiya J. Agric. Res., 37(2): 935-941.

El-Sayed, B.A.; Abd-Elfattah, G.H. and ElShal, S.A. (2008). Improvement of growth and quality of tifway sod by actosol and biofertilizers. J. Biol. Chem. Environ. Sci., 3(1):91-102.

Evans, M. and Li, G. (2003). Effect of humic acid on growth of annual ornamental seedling plugs, Horttechnology, 13(4):661-665.

Hassan, A.A. (2016). Response of Gladiolus Plant to Some Fertilization and 
Antioxidant Treatments. Ph.D. Thesis, Fac. Agric., Minia Univ.

Heng, L.C. (1989). Influence of humic substances on $\mathrm{P}$ absorption in some Malaysian soil under rubber. J. Natural Rubber Res., 4(3):186-194.

Higa, T. and Wididana, G.N. (1991). Changes in the soil microflora induces by effective microorganisms. Proc. $1^{\text {st }}$ Inter. Conf. Kyusei Nature Farming, U.S. Dept. Agric. Washington, D.C. p:153-162.

Jackson, N.L. (1958). Soil Chemical Analysis Constable. Ltd. Co., London, pp. 498.

Janas, R. (2009). Possibilities of using effective microorganisms in organic production systems of cultivated crops. Proplerry Inznierii Polniczei, 17(3):111119.

Kandeel, Y.M.; El-Mahrouk, M.A.; ElTarawy, E.M. and Hegazi, M.A. (2008). Effect of bio, organic and chemical fertilizers on growth, flowering, concrete recovery, oil yield and chemical composition of Jasminium grandiflorum L. proc. $1^{\text {st }}$ Inter. Conf. on ornamentals, Alex. J. Agric. Res., 53(1):67-78.

Khalil, M.M. and Helal, A.A. (1998). Response of geranium to some cultural media and fertilization treatments. Annals of Agric. Sci., Moshtohor, 36(3):1815-1828.

Kobayashi, K.D. and Kaufman, A.J. (2006). Common Gardenia, Cooperative Extention Services, College of Tropical Agric. \& Human resources, Univ. of Hawaii at Manoa.

Lambers, H.; Chapin, F.S. and Pons, T.L. (2000). Plant Physiology \& Ecology. Springer-Verlag, New York Inc., U.S.A.

Little, I.M. and Hills, F.J. (1978). Agricultural Experimentation, Design and Analysis. John Wiley and Sons Inc., New York, U.S.A.
Mengel, K and Kirkby, A. (1987). Principles of Plant Nutrition. $4^{\text {th }}$ edit. International Potash Institute, Bern, Switzerland.

Piper, C.S. (1950). Soil and Plant Analysis. Inter Sci., Pub., New York, pp. 368.

Plummer, D.T. (1971). An Introduction to Practical Biochemistry. Published by McGrow Hill Book Co. (U.K.) Limited.

Primavesi, A.M. (1999). Determination of plant health by their magnetic emanation and its improvement with EM. $5^{\text {th }}$ Inter. Conf. on Kyusei Nature Farming Banghkok, Thailad, 219-225.

Romualad, G. and Tomasz, K. (2010). Effect of effective microorganisms (E.M.) on nutrient contents in substrate and development and yielding of rose (Rosa hybrida) and gerbera (Gerbera Jamesonii). Ecol. Chem. and Engineering, 17(4):505-513.

Saric, M.; Kastrori, R.; Curie, R.; Cupina, T. and Gerie, I. (1976). Chlorophyll determination. Univ. Unoven Sada Parktikum is Fiziologize Bibjoke, Beagard, Hauncna, Anjiga, pp. 215.

Sayed, I.H. (2004). Response of Gladiolus Plants to Some Bio- and Chemical Fertilization. Ph.D. Thesis, Fac. Agric., Minia Univ.

Schroeter-Zekrzewska, A.; Borowiak, K. and Wlna- Maruwka, A. (2016). Effect of light quality and microbioligical inoculum on geranium (Pelargonium Zonale, L.) gas exchange parameters. Notulae Botanicae, Horti Agfrobotanici, Cluj- Napoca, 44(1): 25-33.

Siraj, M.S.; El-Garawany, M.W. and AlGosaibil, A.M. (2001). Effects of manure extracts on soil mineral content and rooting and shooting of Ficus benjamina. The $5^{\text {th }}$ Arabia Hoirt. Conf., Ismailia, Egypt, pp. 127-131.

Thach, N.Q.; Long, C.A.; Liet, V.; Trung, N.V.; Thanh, N.X.; Dich, T.V.; Duong, N.; Tuan, N.K.; Xuan, L.T.H. and Dar. P.V. (1999). Preliminary results of EM 


\section{F.S. Badran et al.}

application in Vietnam, $5^{\text {th }}$ Inter. Conf. On Kyusei Nature Farming. Pangkok, Thailand, 23: 254-260.

Wang, W.J.; Tao, X.H.; Xiang, L. and Qiuxia, Ch. (2015). Effects of effective microorganisms on the growth of 1- yearold container seedlings of three tree species. J. of Southwest Forestry Univ., 35 (3): 1-7.

Williamson, J.F. (1975). Sunset Western Garden Book. Lane Magazine \& Book
Company, Menlo Park, California, U.S.A.

Yukun, X.; Yang, S.X.; YaNing, L.; Jia, T.; Meliling, J.; Xiao Qiang, G. and Wenyu, L. (2014). Effects of compost with different exogenous additives on growth of Gazania sunshine J. of Henan Agric. Sci., 43(10):87-91.

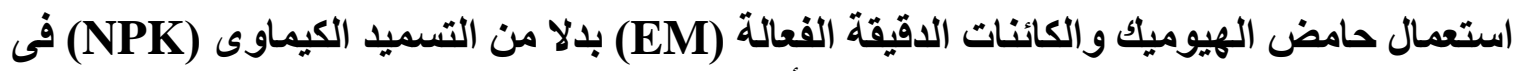
انتاج نباتات أصص الجاردينيا

فاروق صلاح الدين بدران"، محمود عبد الهادي حسن عبده"، أحمد عبد المنعم السيد"، بشره عبداله السيد**و اشرف عبد * كلية الزر اعة، جامعة المنيا، مصر.

أجريت هذه التجربة تحت ظروف الصوبة الزجاجية بمعهد بحوث البساتين، مركز البحوث الزر اعية بالجيزة، مصر

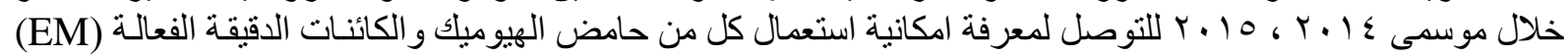

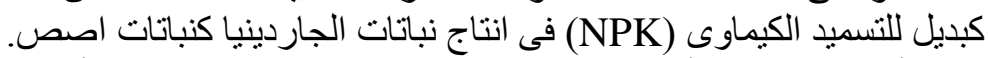

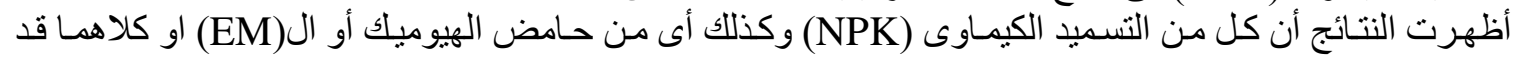

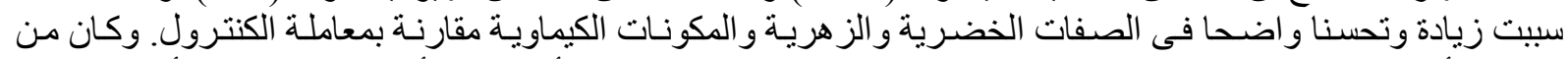

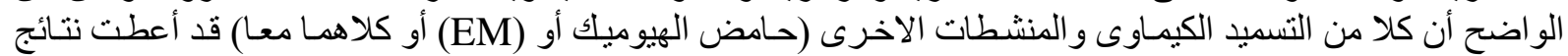

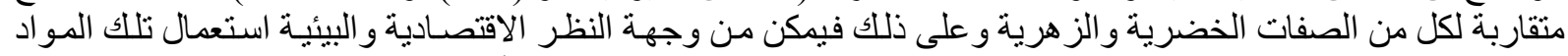

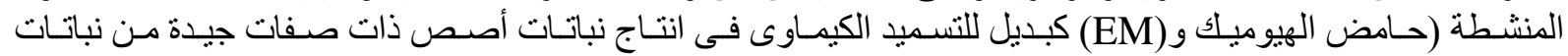
الجاردينيا.
} 

